\title{
A GYNAECOLOGIST LOOKS AT THE TUDORS
}

\author{
by
}

\author{
SIR HECTOR MACLENNAN*
}

WHEN Henry VII ascended the throne after the Battle of Bosworth Field, England was a poor country which had been ravaged by the Wars of the Roses; whose treasury had been squandered and whose coffers were well nigh empty. England was in a state of political instability but Henry VII - the first of the Tudors-was a thrifty Welshman of considerable political sagacity and when he discovered a private army or host of liveried retainers in the employ of any one of the few remaining barons, he fined them for each livery worn, thereby reducing their power and at the same time increasing the wealth of the Treasury. There is little of medical, or perhaps I should say of gynaecological interest in the reign of Henry VII, but he laid the foundation stone of the Tudors so surely that by the time his grand-daughter, Queen Elizabeth, died and ended that dynasty, England had regained stability. Political power rested fully on the shoulders of the queen and her apartment. The morale of the entire nation was in the ascendant and we had assumed a position of authority among the nations which, although occasionally challenged, has never been quite lost.

The eldest son of Henry VII was Prince Arthur who was born in 1486. He died sixteen years later, but his marriage to Katherine of Aragon provided a bone of contention which was to change the face of England long after this innocent young man had been forgotten. Henry had arranged the marriage of his son to Katherine for political reasons-she was the daughter of Ferdinand and Isabella of Spain. A month after her arrival in England she married Arthur at the age of fifteen. He died five months later and this was referred to by Elton as the persistent and fatal sickliness of the Tudor stock. With his death the continuance of the dynasty was in doubt. So much so that Henry VII, who was himself by that time a widower, actually contemplated marriage with his daughter-in-law, Katherine; with the young Queen of Naples, with the Hapsburg princess, Margaret of Savoy, and with Joanna of Castile. In June 1503, however, a year after the death of Prince Arthur, the younger brother Henry-Henry VIII-was betrothed to Katherine of Aragon, having received dispensation from the consequence of affinity from Pope Julius II, and one month after the death of his father in 1509, he fulfilled the dying wish of Henry VII by marrying Katherine, who was six years older than himself.

When we come to consider Henry VIII, I must admit that his extraordinary matrimonial ventures were what first led me to study this period from the gynaecological angle. He was married to Katherine of Aragon for nineteen years; happily married to begin with and, had she been able to bear him a son, there seems little doubt and general agreement on the part of the historians that he would have remained married to her for the rest of his life. While it is well known that she had lost her physical

* Osler Lecture, Faculty of the History of Medicine and Pharmacy, 25 May 1966. Founded on an unpublished presidential address to The Glasgow Obstetrical Society. 


\section{A Gynaecologist Looks at the Tudors}

charms long before he divorced her, it is not only probable but reasonable to expect a king in those days to find outlet for his amorous desires in various younger and more attractive ladies of the court. Her failing charms would not in themselves have presented the chain of events that was to follow. It was solely her inability to produce a male heir. Some extracts from the calendar of state papers in the reign of Henry VIII will, I hope, give you some idea of the intense interest and importance of Queen Katherine's pregnancies.

On 12 April 1518, Sir Richard Pace wrote to Cardinal Wolsey-'It is secretly said that the Queen is with child. Pray God heartily it may be a prince, to the surety and universal comfort of the realm'. He begs Wolsey 'Write a kind letter to the Queen'.

Sebastiano Guistiniano to the Doge of Venice, 6 June 1518:

A report has prevailed for some time of the Queen's pregnancy, an event most earnestly desired by the whole Kingdom. It has been confirmed to me by a most trustworthy person. Visited the Spanish ambassador but could learn nothing from him. My colleague who arrived lately has been despatched by the King and Cardinal (Wolsey) to Flanders, where he will remain until the arrival of the most illustrious infant who is hourly expected.

Henry VIII to Cardinal Wolsey, July 1518.

Two things there be which be so secret that they cause me at this time to write to you myself; the one is that I trust the Queen, my wife, to be with child; the other is chief cause which I am so loath to repair to London ward, because about this time is partly of her dangerous times and because of that I would remove her as little as I may now.

Sir Richard Pace to Cardinal Wolsey, July 1518.

The King arrived this night. The Queen welcomed him with a big belly. Te deum laudamusfisfto be sung at St. Paul's.

Sylvester, Bishop of Worcester to Henry VII, 27 August 1518.

Have replied in the affirmative to the Pope's enquiry if the Queen was with child. The Pope is delighted. Hopes it will be a prince who will be the prop of the universal peace of Christendom.

Sebastiano Guistiniano to the Doge of Venice, 25 October 1518.

The Queen is near her delivery which is anxiously looked for. Prays she may have a son that the King may be at liberty to embark in any great undertaking. [Perhaps a foreign adventure in which his life might be threatened].

Sebastiano Guistiniano to the Doge of Venice, 10 November 1518.

This night the Queen was delivered of a daughter, to the vexation of as many as know it: the entire nation looked for a prince. Had the event taken place before the conclusion of the betrothal that event might not have come to pass.

By the time Katherine was forty she had had a number of miscarriages and premature labours; she had produced five babies who died within days and weeks of delivery, and amongst them three sons. The sole survivor was a girl, Mary, born in 1518 and upon her the safety of the Tudor throne and the tranquility of the country depended. 


\section{Sir Hector MacLennan}

It was not enough. Katherine had not been pregnant for seven years. Her failure to produce a son jeopardized the succession and so Henry looked for an excuse to get rid of her. Their marriage had contravened Leviticus 20 and 21 , which verse declares that a man who marries his brother's widow shall be childless. I have no doubt that Henry sincerely felt that the wrath of God had been visited upon him and that his only course was to have the marriage to Katherine declared null and void. As you are aware, however, the influence of Charles V of Spain was such that the Pope found it impossible to accommodate Henry in this matter and this failure on the part of Rome led to the break.

Before discussing any further the repercussions of the break with Rome, I should like to turn again to Henry's marriage with Katherine of Aragon. She had already been married to Prince Arthur and doubts have been cast as to whether she actually lived with him, although she herself asserted that the marriage had been consummated, and it is not without the bounds of propriety to imagine that a young man, and an active young man of sixteen, in those days might reasonably have cohabited with his wife. It has been suggested that Katherine's dreadful obstetric history could reasonably be attributed to syphilis. Sir Arthur MacNalty, however, in his medical history of Henry VIII, does not regard Henry as being a sufferer from this disease and certainly not in the early years of his life. He advances many reasons for so thinking. He attributes Queen Katherine's bad obstetric history to be due possibly to toxaemia of pregnancy and in this he has gained support from such eminent obstetricians as Sir Eardley Holland and others. He might be right, although I cannot find much evidence to support this point of view. I would like to put forward another theory altogether. If Queen Katherine was Rh. negative and either of her husbands $\mathrm{Rh}$. positive, antibodies might have been set up at a stage which prejudiced her future deliveries. Even if cohabitation did not occur with Prince Arthur it is quite on the cards that Henry VIII might have been Rh. positive and produced a similar series of disasters. If we admit such a possibility, and it is not very far-fetched, then of course this would explain the neonatal deaths which followed. It would also allow of the live birth of Mary who may well have been the product of a negative gene in a heterozygus male parent. How easy it would be today to determine the cause of Queen Katherine's failure to produce a live child and, by the aid of a simple replacement transfusion, one or two of the male children might have been saved, in which case the country would still have been a Roman Catholic one; there would have been no Church of England; Queen Elizabeth would never have come to the throne, and the whole history of our country would have been altered.

Let us consider now from the gynaecological point of view, Anne Boleyn. This was surely the 'shotgun' wedding of all time. She was pregnant when she was married to Henry VIII, who had to create an Archbishop of Canterbury in Cramner before the marriage could be solemnized and the heir legitimized but the heir, much to Henry's disappointment, turned out to be a female-Elizabeth. Anne was given another chance, however, but miscarried. This again caused Henry disappointment but, despite this, she was given a still further chance. On this occasion she miscarried of a male child at the twenty-eighth week, within a few days of the death of Katherine of Aragon. Henry's patience was exhausted. With Katherine of Aragon dead and 


\section{A Gynaecologist Looks at the Tudors}

Anne Boleyn unable to satisfy his obsession for a male heir, he dealt with her as expeditiously as he could and married Jane Seymour. Here again he was unfortunate. In October 1537, George Owen, personal physician to King Henry, along with Sir William Butts, then Dr. Butts, performed a Caesarean section on Jane; while she produced Edward VI, she died in the puerperium. Three years later he married the Flemish Mare-Anne of Cleves. Whether she suffered from dyspareunia, frigidity, or was generally so impossible, we do not know, but Henry could not tolerate her and their marriage was annulled. Eight months later he married Katherine Howard. From the gynaecological point of view there is little reason to believe that she was any more unchaste than many other ladies of the court. By that time Henry was physically decayed although his mental powers were still considerable and he held the reins of power until his death in 1547. Edward VI acceded to the throne at the age of nine. He was never strong and was probably consumptive. He certainly had smallpox and measles and, in the spring of 1553 , he contracted a cold which brought him to his death.

Passing over the Jane Grey episode, he was succeeded by Mary. Mary Tudor in her early years was 'a thin frail woman with tight lips, a low-bridged nose, red hair and a fair complexion which was pretty'. She was very fond of children and very much a woman in her interest in dress. Like every Tudor she was capable of passionate affection but there was never a hint nor a breath of scandal against her. Much of her private life is recorded in the pages of her Account Book and 'these are full of pleasant trivialities' (Prescott). From our point of view, however, it is of interest to note that her great unhappiness in her mother's demotion and the catastrophies which overcame her friends and the Church she loved, resulted in a profound melancholy, which showed itself from time to time; so much so that Francis I, who was interested in her hand, either for himself or for his son, thought it advisable that his ambassador should enquire if this were a symptom of any disease which would make her incapable of childbearing. She was not really a healthy woman and there is more than one entry in her Account of visits by her father's surgeon or others to prescribe for her, to bleed her, or to draw her teeth. Mary was almost as anxious as her father to produce a male heir or to produce any heir which would ensure a succession for the Catholic party. Her marriage with Philip of Spain was a terrible blow to the Protestants and when one considers that in the five years of her reign hundreds of martyrs were burnt at the stake, one can well realize that had she produced a son and heir the Protestants' hope for survival would have been poor indeed.

There is no doubt that Mary Tudor found happiness in her marriage to Philip. She had been married three weeks when she wrote to the Emperor thanking him for sparing his son to her in the midst of war. 'The marriage renders me happier than I can say, as I daily discover in the King, my husband, so many virtues and perfections that $I$ constantly pray God to please him and behave in all things as befits one who is so deeply bounden to him'. Philip himself told his friend, Ruoy Gomez, that when they were alone she almost 'talked love-talk to him' but Gomez wrote 'She is older than we have been told. I believe if she dressed in our fashions she would not look so old and flabby ... To speak quite frankly with you, it would take God to drink of this cup and the best one can say is that the King realizes fully that the marriage was not 


\section{Sir Hector MacLennan}

for any fleshly consideration but in order to cure the disorders of this country and preserve the low countries'.

In the ecstasy of her meeting with Cardinal Pole in the year 1554-who was to advance the Catholic cause in Britain-he announced her pregnant to the public. There was some doubt among the common people at the time as to this pregnancy and these doubts on the part of midwives and others were noted by de Nouailles, the French ambassador, who duly reported them to his master. It undoubtedly made life easier for Mary's sister, Elizabeth, who would succeed to the throne if Mary died in childbed. Like many elderly sterile women who have an obsession for a child she, Mary, had developed a phantom pregnancy. Although the abdominal swelling has been variously attributed to a fibroid or ovarian cyst, the fluctuation in its size would, in my opinion, contradict such a view. Mary was encouraged in her antenatal period by being shown the three fine babies 'born at a birth without ill-effect' to a woman of low stature and great age like herself. On Cardinal Pole's announcement of the pregnancy, and again when false rumour announced the birth of a prince, te deums were sung and the bells of the churches rang out. Her expected date was first given as early in April. In May letters announcing the birth to foreign powers were made ready. She was confined to bed in June at Hampton Court 'surrounded by noble and gentlewomen come in from all over the country to assist at her delivery. Besides these there were the women who should nurse the child and others who should rock the child.' As there was no sign of the onset of labour and, as she became more and more postmature, she became a joke in the court. Renard said at the end of June 'In this Kingdom the Queen's lying-in is the foundation of everything'. He added that if she did not bear a child affairs would be in such a bad way that 'a pen would hardly write them'. It was suggested that she has miscalculated her pregnancy by two months, 'Her Majesty's belly having greatly declined-a sign of the nearer approach of term' (lightening). July passed and she was still not confined. On 3 August she and her husband slipped quietly away from London to Oatlands Palace and on 26 August he departed to Flanders.

While this was a blow to the Catholic party, it must have been greeted with great relief by the Protestants. The humiliation of the situation was almost too much for Mary's husband, who rarely visited her thereafter, and although on another occasion she raised the possibility of pregnancy, she died childless. She was sick for some months before death and showed signs of jaundice and dropsy. It might well be that at this stage she developed a malignant ovarian cyst but the terminal cause of death was an epidemic of what was probably influenza. The throne then passed to Elizabeth. Today, of course, with X-ray and biochemical pregnancy tests, the true state of Mary's health would have been diagnosed at an early stage and the Royal household would not have suffered the indignities consequent upon pseudocyesis. There was never a more classic case of pseudocyesis than that of Queen Mary's and, while it can eventuate from fear of pregnancy, I think most of us will agree that it is more commonly encountered where the desire for pregnancy becomes an obsession; poor Mary was just such a one.

In reflecting upon the Tudors there is no more fascinating subject that Elizabeth and I would like now to consider her medical history. From the general point of view 


\section{A Gynaecologist Looks at the Tudors}

she was certainly the least weakly member. At the age of two and a half she was living at Hunsden under the care of Lady Bryan, an aristocratic nannie, when her mother, Anne Boleyn, was beheaded. It is unlikely that at this tender age the event would have any psychological effect upon the child, except in so far as it deprived her of maternal love and affection. Lady Bryan wrote at that time to Sir Thomas Cromwell about her charge 'My Lady hath great pain with her great teeth and they come very slowly forth and causeth me to suffer her Grace to have her will more than I would'. Undoubtedly Lady Bryan had a difficult task in the upbringing of her Royal charge, especially in the earlier years, but she was a devoted woman and not afraid of tackling the Court on her young charge's behalf.

Shortly after the accession of Queen Mary, when Elizabeth was thought to be involved in the abortive rising of Wyatt, she was summoned by the Queen to attend the Court but pleaded she was unable to do so on account of ill health. It was stated at the time that her body was all swollen up and that she was unable to walk; that her face was puffy. However, Queen Mary sent her doctors to verify this which they did and, when ultimately the Queen insisted on her presence, she could only be brought in a weak state on a litter. Sir Arthur MacNalty suggests this might have been due to an attack of influenza but it seems equally reasonable to postulate that it was due to an attack of acute nephritis and this, as you will appreciate, has a considerable bearing on what might have happened had Elizabeth in point of fact married, as she was so frequently urged to do by her ministers. Abortions, premature labour, accidental haemorrhage and all the concomitants of chronic nephritic toxaemia were never written of in the pages of English history, as Elizabeth remained a virgin Queen. Had the physicians of that time appreciated the significance of her previous illnesses they might not have been so optimistic in their prognosis as to her capabilities of childbearing.

Apart from this 'attack' Elizabeth had sundry other illnesses of a general nature, notably in the spring of 1562 when she fell dangerously ill with smallpox and, as it was written at the time, on the day of the crisis 'death possessed her every joint and the Court mourned her as dying'. While she did not die, the problem of her health raised once more and acutely in the minds of her ministers the problems of succession. Now, of course, we come to one of the greatest gynaecological controversies. Was Elizabeth in point of fact capable of marriage or was there some physical impediment, such as virilism, which lay behind her capricious episodes in courtship. While Elizabeth was under the care of Katherine Parr being as it were 'finished', she came into constant contact with Lord James Seymour of Sudely. According to Neale, he was an intensely ambitious man and even at the age of thirty-eight was anxious to marry Elizabeth. He was prevented from so doing by his brother, Lord Somerset, and his councillors. Before his intentions became obvious it was a regular feature of the life in Katherine Parr's home that Seymour would enter Elizabeth's bedroom and there would ensue a certain amount of 'romping'. She appeared to be fond of Seymour at that time in a girlish way and, according to Neale, the whole incident was innocent enough fooling. Had Elizabeth been sexually aberrant or virilistic, it seems unlikely that the incident would ever have taken place; indeed, the whole affair may be regarded as the calf love of an adolescent girl. 


\section{Sir Hector MacLennan}

Lord Burghley, her wise councillor and one of the earliest statesmen of that great family of statesmen - the Cecils-constantly criticized her failure to marry. Gossip tried to explain this by surmising that Elizabeth was incapable of bearing children. In 1556 the French ambassador when the French King was one of her suitors, asked her physicians about this talk of sterility. The physician replied 'If the King marries her I guarantee ten children and no-one knows her constitution better than I do'. My own view is that if Burghley and the Council had had any doubts as to her menstrual or general physical normality, they would have been able to verify them, especially when the matter was of such vital importance to the State. I have no doubt her ladies in waiting would have been probed as to her menstrual habits and her physicians would have been subjected to close questioning. It should not have been very difficult to determine whether or not she was a normal female. Having read much of the life of Elizabeth, I have not the slightest doubt that she was a very normal woman. If this is admitted then there is some point to the political machinations of her councillors in an endeavour to marry Elizabeth and thereby secure the succession.

During the course of Elizabeth's lifetime there were over twenty possible suitors for her hand, ranging from the strongest aristocrats in England, such as Leicester in the early days and possibly Essex in the later days, to the various crowned heads of Europe, particularly France and Spain, who were at the time in constant conflict; even the subsidiary Scandinavian countries-the Swedish Royal family-had an interest. Elizabeth adroitly avoided each entanglement. It is possible that she might have married Leicester for love but the scandal associated with the death of his wife, Amie Robsart, was such that it would have completely scandalized the public, and Elizabeth was enough of a politician to realize that her hold upon the throne of England depended to a very considerable extent upon the goodwill and loyalty of the people. She used her position and femininity to keep France and Spain in a permanent state of uncertainty; each suitor being advanced only to be repelled almost always on the rock of the religious barrier.

While her failure to marry, however, was a useful gambit in maintaining the balance of power between France and Spain - a most valuable contribution to English foreign policy at that time-there was inherent in it the danger that the succession could not be established. Historians assure us that in a country which was not to develop parliamentary democracy for some three hundred years, the question of succession was of paramount importance to the State and to the prosperity and tranquility of the country. Her failure to marry, therefore, caused great anxiety to her wisest councillors and in particular to Lord Burghley, with whom it became almost an obsession. In this connection, it is interesting to consider for a moment Queen Elizabeth's late attraction for the Duke of Alençon. It was Burghley's last real effort and the Queen's last chance of providing an heir. Here the religious barrier was not so formidable as the Duke was fighting alongside the Dutch and had already fought with the Huguenots. The objection now, however, was that the Queen would have been forty-five or forty-six when the marriage would have taken place. To Walsingham and his party this seemed to place the Queen in jeopardy; to bear a child at this age seemed to him perilous. Gossip had it that she had consultation with her doctors as 


\section{A Gynaecologist Looks at the Tudors}

to whether she could hope for children. It is said that they saw no difficulty. They were probably more tactful than honest. The eminent historian, Neale, maintains that as to the possibility or risk of a first child at her age the relevant fact is not modern medical opinion but her belief-a belief which her most devoted servant, Burghley, shared with his whole soul. I would have thought that modern medical opinion played no part at all in this controversy. The common man and many of her ministers saw the danger and risk. When her Council voted against the marriage, however, the Queen broke down and wept. Her vanity had been wounded. She could not bring herself to believe that she was beyond childbearing. The controversy was intense and passionate. Lord Burghley cited the example of the Duchess of Savoy who was 'physically inferior and older than Her Majesty and yet had given birth to a prince'. The French ambassador in a letter to his sovereign said that his neighbour, an Englishwoman aged fifty-six, was eight months gone with child; that in England it was not thought strange but natural in a woman of good physique and temperament. (It was, of course, to the ambassador's advantage to take this point of view for a sterile marriage to the Frenchman, or death in childbirth, would have brought England under the influence of his own country). Personally, I would be inclined to suggest that his neighbour of fifty-six and eight months gone with child was probably eight months with an ovarian cyst.

The common people took sides on this matter and a Mr. Stubbs pamphleted against the marriage of Elizabeth with Alençon stating that it was a French trick to seek this marriage so eagerly now at the time of most danger to Elizabeth for childbearing. If only Her Majesty would call her most faithful and wise physicians adjuring them on their conscience and their faith to the whole land to speak without thought of pleasing or displeasing any, they would tell her how fearful was the expectation of death. Stubbs and the printers were arrested and condemned to lose their right hands and he imprisoned. I may add that when Stubbs was ultimately deprived of his right hand, he took off his hat with his left, cried 'God Save the Queen' and swooned. The marriage did not take place.

If we turn now from the question of Elizabeth's matrimonial intentions or lack of intentions and examine the woman herself, history tells us that she was a woman of many foibles, one of which was good health. She hated to be ill or even thought to be ill. In 1577 she commanded Leicester to write to Burghley, who was then at Buxton, asking him to send her some of the medicinal waters. When the water arrived she said 'It will not be of the goodness here it is there'. The truth was she had been told that people were talking of it as though Her Majesty had had some sore leg. A year later when a tooth required to come out the physicians were frightened to tell her because 'The Queen doth not or will not so think'. In 1597 she had a 'desperate ache' in her right thumb and, according to Neale, it 'could not or dare not be gout'. 'She was a person of vivacity and willfulness and consequently in the nature of things trying at times'. It is said that 'Her eyes are everywhere. Faults were numerous and she was exacting. Efficiency she would have or know the reason why'. 'Her passionate outbursts were, however, little more than flashes of summer lightning'. Sir John Harrington stated that 'When she smiled it was pure sunshine that everybody did choose to bask in if they could but anon came a storm from a sudden gathering of 


\section{Sir Hector MacLennan}

clouds and thunder fell in wonderous manner on all alike.'

As a gynaecologist reading the historian's description of her life and behaviour, I am forcibly reminded of Hamblen's description of premenstrual tension-'A distinct change in personality; an erstwhile placid co-operative and patient woman may become subject to emotional crises and loss of inhibitions and manifest a querulous argumentative and militant attitude which makes her difficult as an associate'. Had her physicians been able to treat her with progesterone or ammonium chloride, would Raleigh have sailed? Would Drake have singed the King of Spain's beard? Would Mary Queen of Scots have fallen on the scaffold? We can but postulate and, in so doing, realize once more how the practice of medicine may change history.

Recently Trevor-Roper, the Regius Professor of History at Oxford, gave his inaugural address. As you will expect, it was stimulating and highly controversial. He likened the present position of historical research to a large pool of slackwater, in which the present day historian delved deeper and deeper into the mudded depths He made a plea for cutting a new channel in the pool and welcoming the observations and contributions of scientists, biologists and philosophers: 'The stream of their contribution would add liveliness and humanity to what otherwise might become an esoteric pursuit'. In this address I have anticipated his invitation and perhaps added a rivulet of speculation on the life and times of the Tudors, as understood by a gynaecologist. 